\title{
ISOTOPIC INVESTIGATION OF THE SURDULICA GEOTHERMAL SYSTEM
}

\author{
BRANISLAV MILOVANOVIĆ*, SVETISLAV STANKOVIĆ* \\ MIOMIR KOMATINA*, MUNEVERA HADŽIŠEHOVIĆ** \\ MLADEN ŽUPANČIĆ ${ }^{* *}$, NADA MILJEVIĆ ${ }^{* *}$, RISTA STEPIĆC $C^{* *}$ \\ and BOGOMIL OBELIĆ
}

\begin{abstract}
The object of our investigation was to study a mechanism of water formation in the Surdulica geothermal system (recharge area, age and homogeneity of the waters). We collected 56 samples to determine the chemical, stable isotope, ${ }^{14} \mathrm{C}$ and tritium content of the waters. We found large stable isotope variations in precipitation collected at different altitudes, whereas the geothermal waters are largely homogeneous and seasonally independent. Data on springs and rivers, the local meteoric water line and recharge area were obtained. Three groups of groundwater were identified by age - modern from natural springs, old from mines and very old from the Vranjska Banja. Because the initial ${ }^{14} \mathrm{C}$ activity of infiltrated waters from the recharge area is unknown, the age of thermal waters can only be inferred, from $\mathrm{HCO}_{3},{ }^{14} \mathrm{C}$ and ${ }^{3} \mathrm{H}$ content, to be 10,000 to 28,000 years old.
\end{abstract}

\section{INTRODUCTION}

Surdulica is one of the largest geothermal systems in southeast Yugoslavia. The system produces water (ca $100 \mathrm{~L} / \mathrm{s}$ cold water) and geothermal energy (near $70 \mathrm{~L} / \mathrm{s}, 80^{\circ}-126^{\circ} \mathrm{C}$ ). A drainage system of ca $200 \mathrm{~L} / \mathrm{s}$ cold water is being planned by building underground galleries and increasing exploitation of the thermal springs from $50-100 \%$.

Investigations of the system started in the last century (Žujović, 1893) and continued in the second half of this one (Babović, Vukanović \& Krajačić, 1970; Anderson, 1985). Geological formations of the Vranje Tertiary basin, its structure, tectonics and thermal waters have been extensively surveyed. Environmental isotopic investigations began in 1986 and are now sponsored by the IAEA.

We expect that isotopic measurements will provide information on the source from which thermal springs in the Vranjska Banja are supplied. D, ${ }^{18} \mathrm{O},{ }^{3} \mathrm{H}$ and ${ }^{14} \mathrm{C}$ measurements and analysis of chemical water composition should define a recharge area and process of groundwater formation on its path from infiltration to geothermal appearance.

Recent results of isotopic investigations are presented here. They consist in $\delta \mathrm{D}-\delta^{18} \mathrm{O}$ relationship and ${ }^{3} \mathrm{H}$ and ${ }^{14} \mathrm{C}$ content of groundwater for age determination.

\section{GEOLOGICAL BACKGROUND}

The Surdulica geothermal system occupies the Besna Kobila mountain massif $(1922 \mathrm{~m}$ asl) and belongs to the geotectonic region of SerbianMacedonian mass predominantly formed of Proterozoic crystalline schists. The hydrogeothermal system itself is in the neogen-fissured granodiorite

* Geozavod, 11000 Belgrade, Yugoslavia

** Boris Kidrič Institute of Nuclear Sciences, Vinča, POB 522, 11001 Belgrade

† Ruđer Bošković Institute, POB 1016, 41001 Zagreb, Yugoslavia 


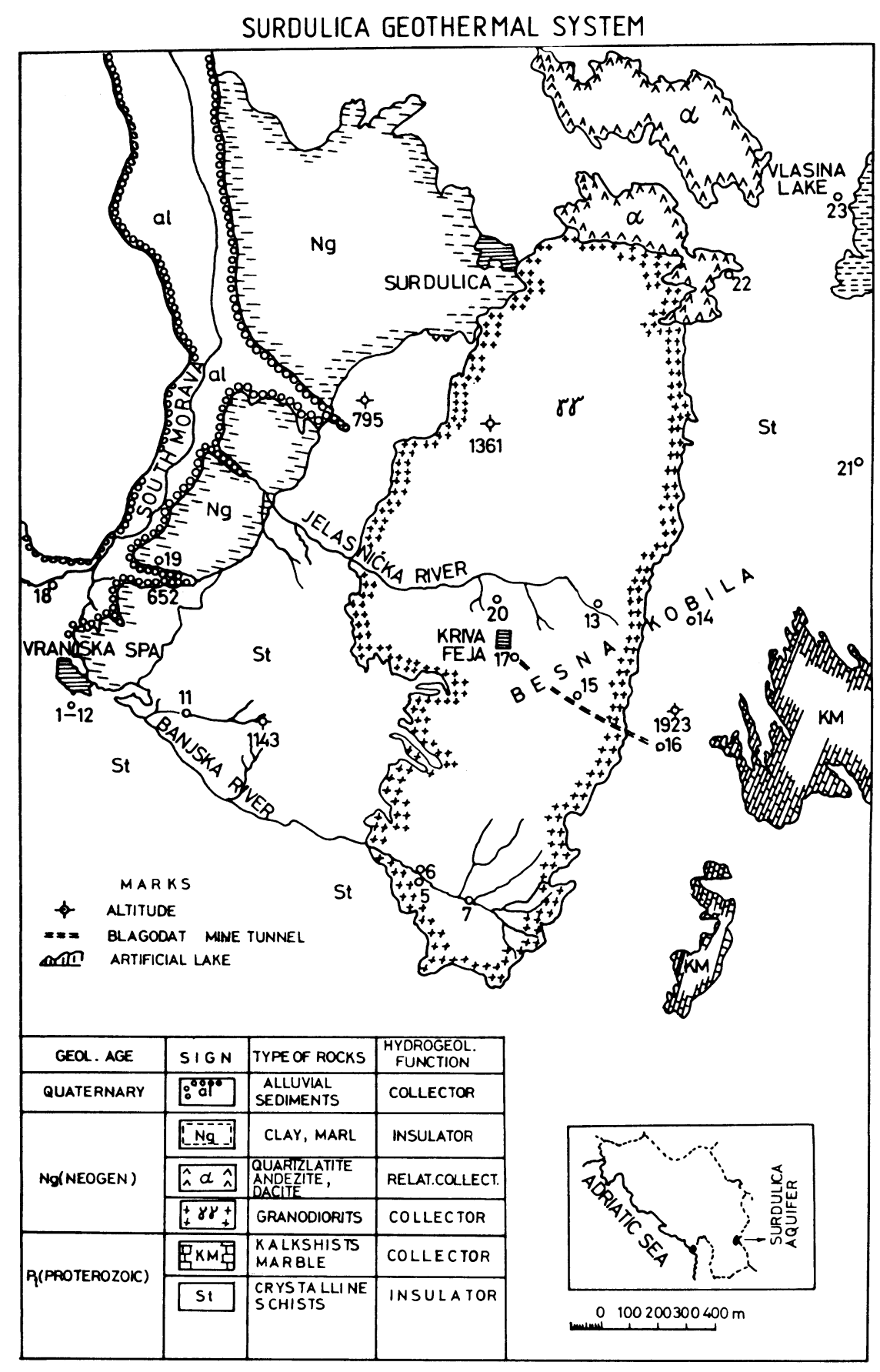

Fig 1. Geological map of area under investigation 
MODEL OF IHE SURDULICA GEOTHERMAL SYSTEM

O MOOEL OF THE HYOROGE OLOGICAL FUNCTION
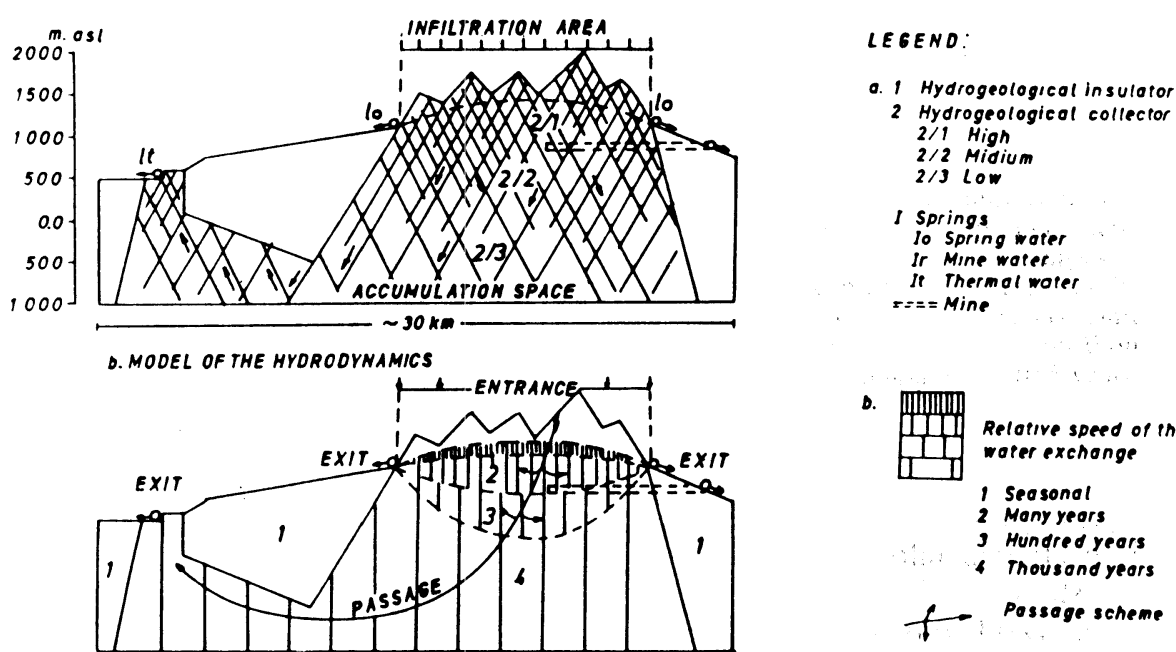

b.

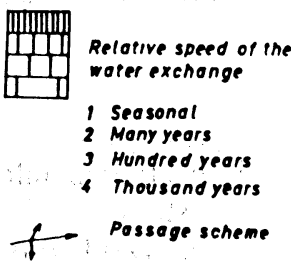

Fig 2. Model of the Surdulica geothermal system

aquifer, surrounded by insulating crystalline schists, the uncovered top of which represents an assumed recharge area (Fig 1).

Geophysical measurements have shown that sedimentary layers of the Vranje valley are very heterogeneous with large faults and decreasing porosity with depth (Fig 2). In the direction of the South Morava valley, the steeply sloping mountainsides of the Surdulica system are cut with deep rivers and brooks, the streams of which are generally perpendicular to the flow of South Morava (Jelašnička and Banjska Rivers).

This region is characterized by a transitional regime between moderate continental and Mediterranean climate. The average precipitation is ca 600 and $1000 \mathrm{~mm}$ in the valley and higher mountains, respectively. During the winter (October-March) the predominant precipitation (ca 60\%) is snow which remains up till May.

Natural thermal springs appear in the foothills of a schist massif at ca $400 \mathrm{~m}$ alt and in the area of $200-400 \mathrm{~m}$. A few shallow (50-200m deep) and two deeper $(1000-2000 \mathrm{~m})$ boreholes were drilled. The capacity of the deepest is $30 \mathrm{~L} / \mathrm{s}$ with temperature of $126^{\circ} \mathrm{C}$. There are a great number of cold springs with total capacity of ca $100 \mathrm{~L} / \mathrm{s}$ at elevations between 400 and $1600 \mathrm{~m}$. In addition, drainage waters $(40-70 \mathrm{~L} / \mathrm{s})$ flow out of the Blagodat mine $(1300 \mathrm{~m}$ asl). Thermal waters show bicarbonate sulphated sodium character; slightly alkali $(\mathrm{pH}=7.1-7.5)$, mineralized $(1.15-1.27 \mathrm{gr} / \mathrm{L})$ with low hydrogensulfide $(1.05-1.20 \mathrm{mg} / \mathrm{L})$ and high fluoride and iron concentrations. Carbonate content in water increases with depth in the aquifer, which is obvious from concentrations in cold and geothermal waters (Table 1). 


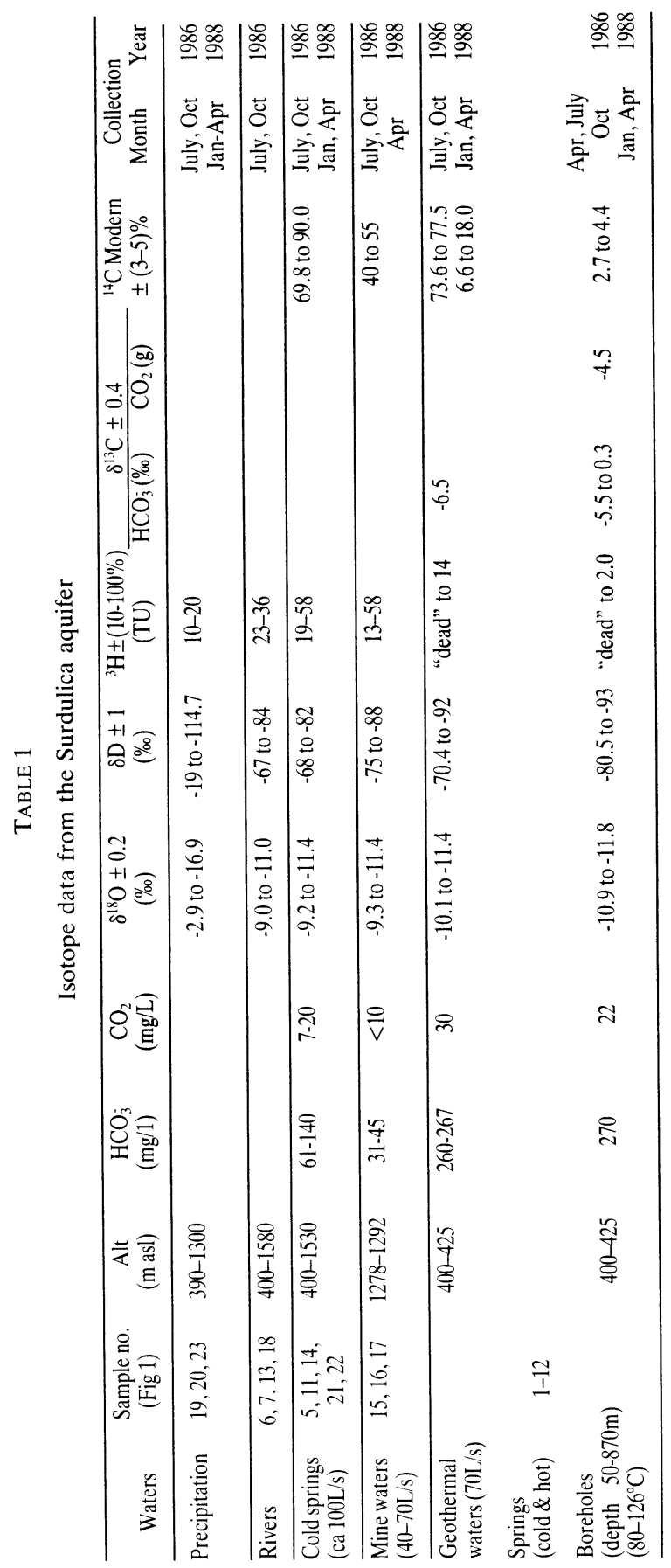




\section{SAMPLING AND ANALYSES}

The monthly precipitation and individual samples from cold natural springs, rivers, mines, thermal springs and boreholes were analyzed. Sample locations are shown in Figure 1. Because of snow and unpredictable weather conditions, sampling is difficult from October to April. During 1986 the samples were collected at the end of the rainy and dry seasons, in July and October, and that has been continued in 1988 .

At more than 25 locations, 56 analyses of $\mathrm{D},{ }^{18} \mathrm{O}$ and ${ }^{3} \mathrm{H}$ were performed as well as 18 analyses of ${ }^{14} \mathrm{C}$ and 6 of ${ }^{13} \mathrm{C}$ (in TDIC and $\mathrm{CO}_{2}$ gas) ${ }^{18} \mathrm{O}$ analyses were carried out according to the technique outlined for equilibration of $\mathrm{CO}_{2}$ with water at $25^{\circ} \mathrm{C}$ (Epstein \& Mayeda, 1953). Deuterium data were obtained by the reduction of water with zinc at $460^{\circ} \mathrm{C}$ (Coleman et al, 1982). ${ }^{13} \mathrm{C}$ content was analyzed as $\mathrm{CO}_{2}$ gas which was produced in the acid decomposition of precipitated carbonates by phosphoric acid (IAEA, 1981). Stable isotope ratios were measured by using double collector mass spectrometers Micromass 602 and SIRA 12. The isotope content is reported in $\delta \%$ relative to standards V-SMOW for $\delta^{18} \mathrm{O}+\delta \mathrm{D}$ and PDB for $\delta^{13} \mathrm{C}$. The $2 \sigma$ errors for these determinations are $0.2,1$ and $0.4 \%$, respectively. Tritium activity was measured by a liquid scintillation spectrometer (Packard 3380) with electrolysis enrichment (Hut, 1986) and expressed in TU $\pm(10-100 \%)$. The activity of ${ }^{14} \mathrm{C}$ was obtained using the same spectrometer after benzene synthesis and internal gas counting with $\mathrm{CH}_{4}(\mathrm{Srdoč}$, Breyer \& Sliepčević, 1971). It is expressed in \% modern with error of 3 to $5 \%$.

\section{RESULTS}

The results of investigations are summarized in Table 1. Maximum variations of isotopes and carbonates during the period under consideration are shown in Figure 3.

Observed differences in $\mathrm{D}$ and ${ }^{18} \mathrm{O}$ content are the greatest in precipitation and the lowest in geothermal water. For precipitation, collected at elevations between 400 and $1300 \mathrm{~m}$ during a year, data range from -2.9 to $-16.9 \%$ for $\delta^{18} \mathrm{O}$, and from -19.0 to $-114.7 \%$ for $\delta \mathrm{D}$. The values for geothermal waters in the Vranjska Banja are independent of sampling season and vary between -10.9 and $-11.8 \%$ for $\delta^{18} \mathrm{O}$, and between -80.3 and $-93.0 \%$ for $\delta \mathrm{D}$. The range for the fluctuation of springs and rivers is -9.0 to $-11.4 \%$ for $\delta^{18} \mathrm{O}$, and -67.0 to $-88.0 \%$ for $\delta \mathrm{D}$.

In the modern waters from the study area, the lowest ${ }^{3} \mathrm{H}$ content is recorded in precipitation (10 to $28 \mathrm{TU}$ ) and the highest in springs and mine waters (13 to $58 \mathrm{TU})$, especially above $800 \mathrm{~m}$ asl. Probably, the higher ${ }^{3} \mathrm{H}$ concentrations in the latter waters are a result of different drainage rates through the system. The mine waters drain a part of aquifer under the level of permanent saturation (Fig 2), where there are many years' accumulation of meteoric waters with higher ${ }^{3} \mathrm{H}$ concentrations. Similarly, springs with higher ${ }^{3} \mathrm{H}$ concentrations come from local, slow-moving streams of groundwater. In July the ${ }^{3} \mathrm{H}, \mathrm{D}$ and ${ }^{18} \mathrm{O}$ contents of precipitation, spring and mine waters are higher than or equal to their values in October, but for rivers it is vice versa. 


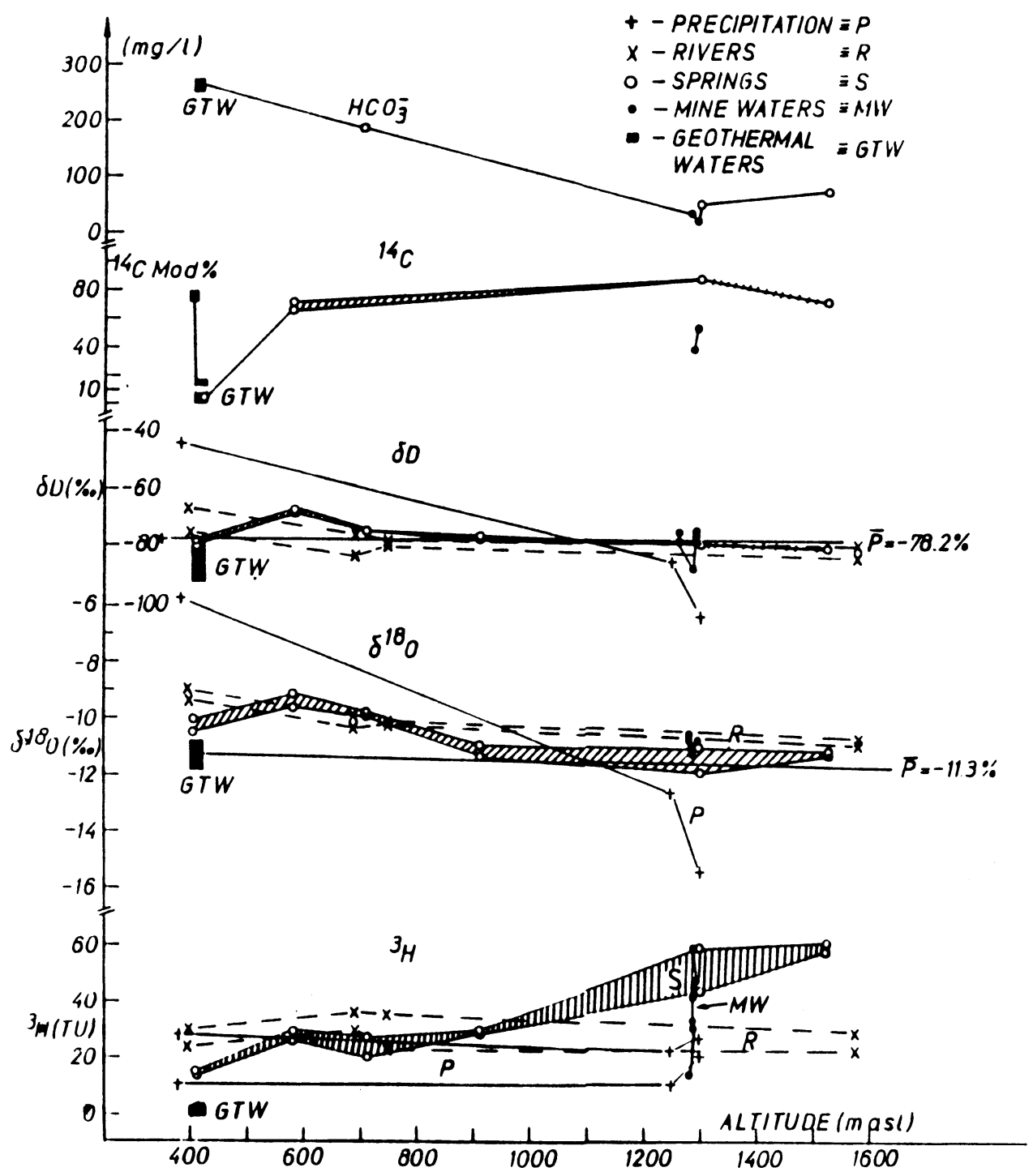

Fig 3. Content of isotopes and carbonates in investigated waters (patterned and open areas represent limits of measured variations)

Geothermal waters, within limits of error, are tritium free, independent of sampling season, water depth or sample source. An absence of tritium suggests that we are dealing with older waters, consistent with observed ${ }^{14} \mathrm{C}$ concentrations of only 2.7 to $6.6 \%$ modern. Contrary to thermal waters, the ${ }^{14} \mathrm{C}$ content varies from 69.8 to $90.0 \%$ modern in springs and from 40 to $55 \%$ in mine waters. 
The ${ }^{13} \mathrm{C}$ content of $\mathrm{HCO}_{3}$ in water from different depth of boreholes lies in the range of -6.5 to $0.3 \%$. Only from one borehole $(\mathrm{B}-1)$ was the ${ }^{13} \mathrm{C}$ concentration in $\mathrm{CO}_{2}$ gas analyzed and a value of $-4.5 \pm 0.3 \%$ obtained.

$\mathrm{HCO}_{3}^{-}$and $\mathrm{CO}_{2}$ content were also determined during sampling. Mine and spring waters from altitudes higher than $1300 \mathrm{~m}$ are characterized by concentrations of $\mathrm{HCO}_{3}^{-}$and $\mathrm{CO}_{2}$ lower than $80 \mathrm{mg} / \mathrm{L}$ and $10 \mathrm{mg} / \mathrm{L}$, respectively. Going down the aquifer these concentrations increase, and in springs (below $600 \mathrm{~m}$ asl) and geothermal waters, reach values of $140-270 \mathrm{mg} / \mathrm{L}$ for $\mathrm{HCO}_{3}$, and $20-30 \mathrm{mg} / \mathrm{L}$ for $\mathrm{CO}_{2}$.

\section{INTERPRETATION OF ISOTOPIC RESULTS}

Measured $\delta \mathrm{D}$ and $\delta^{18} \mathrm{O}$ values of precipitation were fitted by least squares to the following relationship (Fig 4):

$$
\delta \mathrm{D}=(6.7 \pm 0.1) \times \delta^{18} \mathrm{O}-(1 \pm 2)
$$

with $\mathrm{n}=10$, a correlation coefficient of $\mathrm{r}=0.998$ and a standard error of estimation of $\sigma= \pm 2.2 \%$. The equation shows that the system is characterized by a lower value of deuterium excess than that of the world water line, while the slope is similar (Gat \& Gonfiantini, 1981). Values of $\delta \mathrm{D}$ and $\delta^{18} \mathrm{O}$ for other examined waters are gathered under a local meteoric water line in the limits of its error. Geothermal water data also lie within the limits of error of the regional precipitation line.

The gradients for altitude effects calculated from the relations $\delta^{18} \mathrm{O}(\delta \mathrm{D})$ $=\mathrm{f}$ (altitude) for springs and mine waters are $-0.17 \pm 0.06 \% / 100 \mathrm{~m}$ for $\delta^{18} \mathrm{O}$

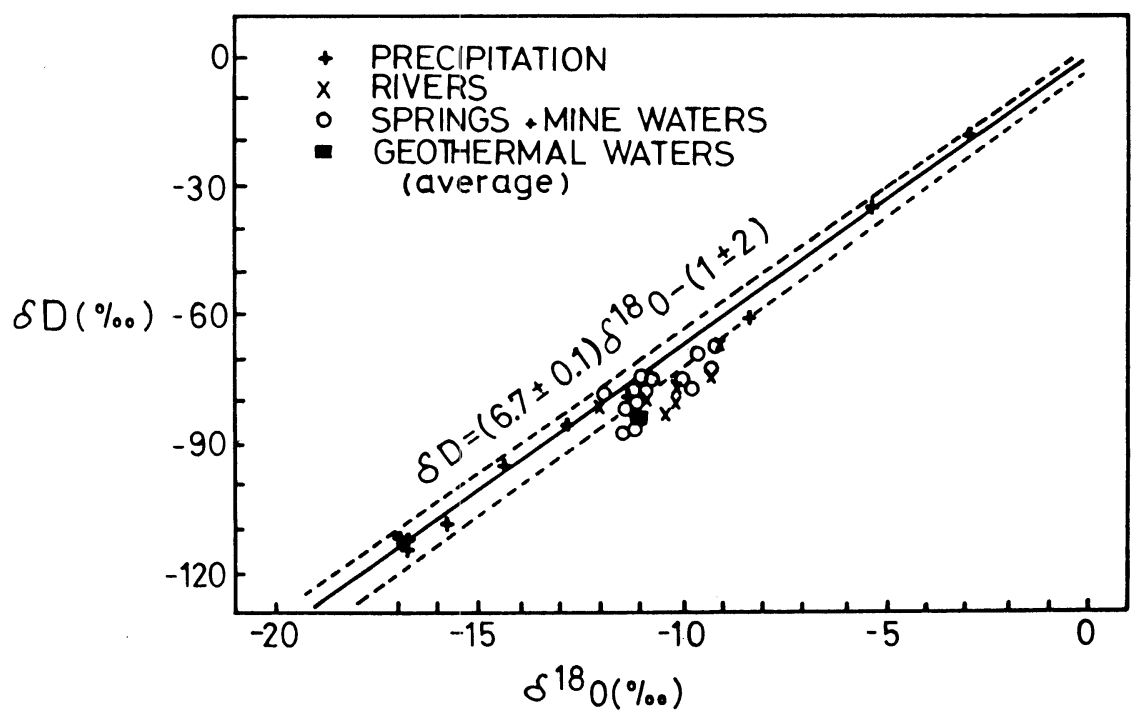

Fig 4. Relationship between $\delta \mathrm{D}$ and $\delta^{18} \mathrm{O}$ in precipitation and other waters 
and $-1.1 \pm 0.3 \% / 100 \mathrm{~m}$ for $\delta \mathrm{D}$. These values for weighted precipitation are rather higher, $-0.9 \pm 0.2 \%\left(\delta^{18} \mathrm{O}\right) / 100 \mathrm{~m}$ and $-6 \pm 1 \%(\delta \mathrm{D}) / 100 \mathrm{~m}$. The noticed distinctions could result mostly from the indicated gradient for precipitation because it was obtained only from two elevations ( 390 and $1300 \mathrm{~m}$ asl) with insufficient numbers of data during a year. Consequently, the estimated values are less accurate. On the other hand, the obtained gradient for spring water reflects some averaging of rainwater from different altitudes and different residence times of water through the aquifer.

According to precipitation isotope gradients, compared with mean isotopic composition of geothermal waters $\left(\delta^{18} \mathrm{O}=-11.1 \%\right.$ and $\overline{\delta \mathrm{D}}=-84.8 \%$ ), recharge area lies above $1100 \mathrm{~m}$ asl. Including all cold springs, this area could be extended between 1100 and $1800 \mathrm{~m}$ asl. Thus, we can conclude that only a part of an open aquifer works as the recharge area for geothermal waters.

\section{Groundwater Formation in the System}

Thus far, both geological and isotopic investigations indicate that the source of water in the thermal aquifer is meteoric. Waters which have infiltrated higher parts of the system penetrate along faults into its depth forming many aquifers with different residence times. According to the concentrations of ${ }^{3} \mathrm{H},{ }^{14} \mathrm{C}$ and carbonates, investigated groundwater can be classified into three groups.

The first group is characterized by fast water exchange and higher content of these isotopes $\left({ }^{3} \mathrm{H}\right.$ between 19 and 58TU, and ${ }^{14} \mathrm{C}$ between 69.8 and $90 \%$ modern). These waters are from natural springs located above or on a contact of open aquifer with an insulator (Fig 2).

The older waters, which were identified in the mine galleries, also contain tritium (13 to 58TU) and belong to the second group. Their content of ${ }^{14} \mathrm{C}$ from 39.7 to $55 \%$ modern corresponds to an age of $3000-6000 \mathrm{yr}$ (for $\mathrm{A}_{0}=85 \%$ ). They describe a zone of slower water exchange, and their very low content of $\mathrm{HCO}_{3}^{-}(31-45 \mathrm{mg} / \mathrm{L})$ indicates that practically the whole flowpath is through granodiorite. The fact that waters in mine galleries are older than those in natural springs at the same or rather lower elevations (Table 1) shows that the aquifer is hydrologically anisotropic, ie vertically divided by water-impermeable or somewhat impermeable barriers.

The third zone is characterized by tritium-free waters with very low ${ }^{14} \mathrm{C}$ content $(2.7-6.6 \%$ modern $)$. They occur at the Vranjska Banja location. The low content of ${ }^{14} \mathrm{C}$ and absence of tritium are a clear mark of the existence of groundwater $>10,000 \mathrm{yr}$ old. Because the initial activity of infiltrated waters in the recharge area has not been determined, the age of these waters cannot be calculated exactly (Fontes, 1983). For $\mathrm{A}_{0}=85 \%$ of modern ${ }^{14} \mathrm{C}$, their age is in a range of $10,000-28,000$ years. Measured ${ }^{13} \mathrm{C}$ values of TDIC $>-5.5 \%$ indicate dilution by "dead" carbon, so that the age of the waters may be less than the range indicated.

The origin of $\mathrm{CO}_{2}$ and carbonates in this system has not been determined yet. This task remains for future studies, in order to arrive at a better determination of the thermal water age. 


\section{CONCLUSION}

Isotopic and chemical composition of Surdulica groundwater indicates a complex hydrogeological structure of this granodiorite massif. In the system, shallow waters from natural springs and two types of old waters have been identified: 1 ) younger $\left(40-55 \%\right.$ of modern $\left.{ }^{14} \mathrm{C}\right)$, and 2$)$ tritiumfree with very low ${ }^{14} \mathrm{C}$ content $(2.7-6.6 \%$ modern $)$.

Increasing $\mathrm{HCO}_{3}^{-}(30-270 \mathrm{mg} / \mathrm{L})$ content from top to bottom of the system and relatively high values of $\delta^{13} \mathrm{C}(-5.5-0.3 \%)$ indicate dilution with "dead" carbon during geothermal water formation. Thus, for more precise estimates of age, better knowledge of carbon chemistry is required.

For the geothermal waters, the recharge area determined from $\delta \mathrm{D}$ and $\delta^{18} \mathrm{O}$ altitude variations in precipitation and cold waters lies above $1100 \mathrm{~m}$ asl, and corresponds to the Besna Kobila Mountain.

It is necessary to continue observations of $\mathrm{D}$ and ${ }^{18} \mathrm{O}$ contents in precipitation in order to establish a more confident "local" meteoric water line. Afterwards, based on the position of this line and isotopic composition of geothermal waters $\left(\delta \mathrm{D}, \delta^{18} \mathrm{O}\right)$, something more about processes of their formation can be said. Verification of the Surdulica geothermal system requires further study and some new boreholes. Recent surveys did not allow determination of the size of the geothermal aquifer, which is important for planning serious exploitation.

\section{ACKNOWLEDGMENTS}

Partial financial support of this study by the IAEA (Research Contract No. 4852/RB) is gratefully acknowledged.

\section{REFERENCES}

Anderson, E, 1985, Review of Vranjska Banja geothermal prospect, scientific and engineering aspects: Wellington, New Zealand, GENZ - Geothermal Energy New Zealand, Ltd, p 1224.

Babović, M, Vukanović, M, Krajačić, V, Rakić, M and Dimitrijević, M, 1970, Basic geological map, Chart Vranje 1: 1000 000: Geozavod, Fed Geol Inst, Belgrade.

Coleman, M L, Shepherd, T J, Durham, J J, Rouse, J B and Moore, G R, 1982, Reduction of water with zinc for hydrogen isotope analysis: Anal Chem, 54, p 993-995.

Epstein, S and Mayeda, T K, 1953, Variations of the ${ }^{18} \mathrm{O} /{ }^{16} \mathrm{O}$ ratios in natural waters: Geochim et Cosmochim Acta, v 4, p 213-224.

Fontes, J C, 1983, Dating of groundwater, in IAEA/UNESCO Guidebook in nuclear techniques in hydrology: IAEA, Vienna, Tech repts ser no. 91, p 285-317.

Gat, J R and Gonfiantini, R, eds, 1981, Stable isotope hydrology deuterium and oxygen-18 in the water cycle: IAEA, Vienna, Tech repts ser no. 210, p 103-142.

Hut, G, 1986, Intercomparison of low-level tritium measurements in water: IAEA, Vienna.

IAEA, 1981, Preparation of carbon dioxide for C-14 measurements: Tech procedure note no. 25 .

Srdoč, D, Breyer, B and Sliepčević, A, Ruđer Bošković Institute radiocarbon measurements I: Radiocarbon, v 13, no. 1, p 135-140.

Žujović, J M, 1983, Thermal springs of Vranjska Banja, in Geology of Serbia: Serbian Royal Acad, Belgrade, Vol II - Granite, p 54-73. 